\title{
Aberrant Expression of Disintegrin- Metalloprotease Proteins in the Formation and Progression of Uterine Cervical Cancer
}

\author{
Mohammed Shaker ${ }^{a, b}$ Yuhki Yokoyama ${ }^{a}$ Seiji Mori ${ }^{a}$ Masahiko Tsujimoto ${ }^{d}$ \\ Naomasa Kawaguchi ${ }^{a}$ Tohru Kiyono $^{c}$ Toru Nakano $^{\text {b }}$ Nariaki Matsuura ${ }^{a}$ \\ Departments of a Molecular Pathology and ${ }^{b}$ Stem Cell Pathology, Graduate School of Medicine, Osaka University, \\ Osaka, ' Virology Division, National Cancer Center Research Institute, Tokyo, and 'Department of Pathology, \\ Osaka Police Hospital, Osaka, Japan
}

\section{Key Words}

Disintegrin · Cervix · Cervical intraepithelial neoplasia •

Tissue inhibitor of metalloprotease $\cdot$ ADAM $\cdot$ ADAMTS

\begin{abstract}
Objective: Dysregulated expression of disintegrin-metalloprotease proteins [a disintegrin and metalloproteases (ADAMs) and ADAMs with thrombospondin motif (ADAMTSs)] has been reported in many types of cancers and is believed to play an important role in cancer formation and metastasis. However, little is known about the expression of ADAMs and ADAMTSs in the development of human cervical cancer. Methods: Reverse transcriptase polymerase chain reaction and immunoblotting were performed to assess the expression of several disintegrin-metalloproteases and tissue inhibitors of metalloproteinases (TIMPs) in squamoustype cervical cancer cells and oncogenically modified keratinocytes (immortalized human cervical keratinocytes transduced with human papilloma virus-16 E6/E7 proteins with or without oncogenes). Immunohistochemistry of ADAM-9, ADAM-10 and TIMP-3 was performed on 31 primary human cervical tissue specimens of preinvasive and invasive cervical carcinoma. Results: mRNA levels of ADAM-9, ADAM-10, ADAM-12, TIMP-2 and TIMP-3 were upregulated as cervical
\end{abstract}

cells progressed from dysplastic to malignant lesions compared to normal cervical cells. These results were corroborated at the protein level by Western blot analysis and immunohistochemistry. Conclusion: The expression of disintegrin-metalloproteases and their endogenous regulators was dysregulated during cervical carcinogenesis. The aberrant expression of ADAMs might contribute to the pathogenesis of cervical cancer formation and progression.

Copyright $\odot 2011$ S. Karger AG, Basel

\section{Introduction}

Cervical carcinoma, a malignant neoplasm of cervix uteri, is the second-most common cancer in women worldwide. Every year, more than 550,000 new cases of cervical cancer are diagnosed, and it contributes to the deaths of more than 310,000 women, the majority of which occur in the developing countries [1]. Squamous cell carcinoma is the most common histological type of cervical carcinoma, representing about $85-90 \%$ of all cases. Numerous studies have provided evidence that persistent infection with certain 'high-risk' human papilloma virus (HPV) strains is one of the initiating factors in the development of uterine cervical carcinoma [2]. The

\section{KARGER}

Fax +41613061234 E-Mail karger@karger.ch www.karger.com (c) 2011 S. Karger AG, Basel

$1015-2008 / 11 / 0783-0149 \$ 38.00 / 0$

Accessible online at:

www.karger.com/pat
Prof. Dr. Nariaki Matsuura

Department of Molecular Pathology, Graduate School of Medicine, Osaka University 1-7 Yamadaoka, Suita

Osaka 565-0871 (Japan)

Tel. +81 66879 2595,E-Mail matsuura@sahs.med.osaka-u.ac.jp 
integration of HPV genome into the host DNA causes malignant transformation through the integration of viral E6 and E7 oncogenes into the host genome; these oncogenes deregulate the cell cycle regulators p53 and retinoblastoma proteins $[2,3]$. However, most infections resolve spontaneously and pass uneventfully. Progression of low-grade squamous intraepithelial lesions (LSILs) to high-grade squamous intraepithelial lesions (HSILs) and subsequent invasion is linked to the persistence of HPV infection and to genetic and/or epigenetic alteration(s), which may act synergistically or independently [4].

A disintegrin and metalloproteases (ADAMs) are transmembrane proteins with broad tissue distribution. The structure of ADAMs is closely related to that of snake venom proteins [5]. ADAMs are multidomain proteins that comprise a prodomain, a zinc metalloprotease domain, a disintegrin domain, a cysteine-rich region, an epidermal growth factor-like region, a transmembrane domain and a cytoplasmic domain.

The ADAM with thrombospondin motif (ADAMTS) family of proteins is structurally related to ADAMs; however, they lack epidermal growth factor-like sequences and the transmembrane domains and are characterized by the presence of a variable number of thrombospondinlike motifs. Hence, they are soluble secreted proteins [6]. ADAMs play critical roles in physiological, inflammatory and pathological conditions through ectodomain shedding of cell ligands and the modulation of cell-cell and cell-matrix interactions [7-9]. ADAMs are involved in specific cellular processes including fertilization, neurogenesis and adipogenesis [10-13].

An increasing body of evidence indicates that disintegrin-metalloprotease proteins are involved in the formation and progression of a variety of cancers [14, 15] through regulation of cell adhesion, migration and invasion. ADAMTS- 1 was found to be a regulator of metastasis depending on its catalytic domain and protein status $[16,17]$. Taken together, these findings may suggest a pivotal role of ADAMs and ADAMTSs as a distinct group of oncogenes or tumor suppressor proteins [18]. Disintegrin-metalloprotease molecules share structural homology with the matrix metalloproteases (MMPs), a family of zinc-dependent proteases, in that they share a metalloprotease domain. However, half of ADAMs exert catalytic activities $[19,20]$. Tissue inhibitors of metalloproteases (TIMPs), known to be potent physiological inhibitors of MMPs, can also selectively regulate the activities of specific ADAMs and ADAMTSs [21-23].

The molecular mechanisms underlying progression from normal epithelium through preinvasive cervical le- sions to invasion are complex and poorly understood. Proteolysis, due to upregulation of proteases, is one of the hallmarks of cancer progression [24]. Members of the MMP family are implicated in the pathogenesis and progression of cervical carcinoma $[25,26]$. Because of the close similarity between MMPs and the disintegrinmetalloprotease family, we speculated that ADAMs and ADAMTSs might play a role in cervical tumorigenesis.

\section{Materials and Methods}

\section{Cell Lines}

The cervical cancer cell lines of the squamous type (QG-U, SKG-IIIb and Yumoto) were kindly provided by Dr. Minoru Ueki (Osaka Medical College, Osaka, Japan) [27]. QG-U and SKG-IIIb cell lines are HPV positive, while the Yumoto cell line is HPV negative [28]. Cells were cultured in RPMI-1640 (Nissui, Tokyo, Japan) supplemented with $10 \%$ heat-inactivated fetal bovine serum (Biowest, Tokyo, Japan) and cultured at $37^{\circ} \mathrm{C}$ with $5 \% \mathrm{CO}_{2}$. The in vitro multistep cervical carcinogenesis model was chosen to assess the expression profile of proteases at the mRNA and protein levels during the course of cervical carcinogenesis. The model of oncogenically modified human cervical keratinocytes has been thoroughly described in previous literature [29]. Briefly, human cervical keratinocytes (HCK) were obtained from donors with informed consent. Keratinocytes were sequentially transduced with hTERT, HPV-16 E6E7 (viral oncoproteins) and/or oncogene(s) of interest such as Hras and c-Myc. Immortalized HCK transduced with HPV-16 E6E7 have similar characteristics to LSILs. HCK transduced with E6E7 and Hras oncogenes are similar to HSILs. Immortalized HCK with E6E7/Hras/c-Myc oncogenes had features of invasive cervical cancer. The latter 2 types of oncogenically modified cells were confirmed to be resistant to contact inhibition and differentiation. Cells were grown in defined keratinocyte serum-free medium (Gibco, New York, N.Y., USA) supplemented with growth supplement (Gibco) and cultured at $37^{\circ} \mathrm{C}$ with $5 \% \mathrm{CO}_{2}$.

\section{RNA Extraction and Reverse Transcription Polymerase}

Chain Reaction

Total RNA was extracted using sepasol-RNA I (Nacalai Tesque, Kyoto, Japan). Genomic DNA contamination was eliminated by use of DNase (Promega, Madison, Wisc., USA). A volume of $5 \mu \mathrm{g}$ of total RNA measured with a U-1800 spectrophotometer (Epson, Japan) was reverse transcribed with 5 units of reverse transcriptase (RT; Promega) and mixed with $0.5 \mu \mathrm{g}$ of oligo (dT), $5 \mu \mathrm{l}$ of $5 \times$ buffer, $2 \mu \mathrm{l}$ of $2 \mathrm{~mm}$ deoxynucleotide triphosphate mixture and 40 units of RNasin. The resulting mixture $(25 \mu \mathrm{l})$ was incubated at $42^{\circ} \mathrm{C}$ for $60 \mathrm{~min}$ and then at $65^{\circ} \mathrm{C}$ for 15 min. A thermal cycler (GeneAmp ${ }^{\circledR}$ PCR System 9700, PE Applied Biosystems) was used for the PCR reaction. In a PCR tube, $12.5 \mu \mathrm{l}$ of Amplitaq Gold ${ }^{\circledR}$ PCR master Mix (Roche, N.J., USA), $9.5 \mu$ l of distilled water, $1 \mu$ l of each specific paired primer (Operon, Japan) and $1 \mu \mathrm{l}$ of cDNA were mixed together. The primer sequences are given in table 1 . The resultant mixture was denatured at $95^{\circ} \mathrm{C}$ for $5 \mathrm{~min}$, followed by cycles of $30 \mathrm{~s}$ at $95^{\circ} \mathrm{C}, 45 \mathrm{~s}$ at the respective annealing temperature (table 1 ) and $1 \mathrm{~min}$ at $72^{\circ} \mathrm{C}$ as an extension 
Table 1. The primer sequences designed for the RT-PCR analysis

\begin{tabular}{|c|c|c|c|c|c|}
\hline Target gene & & Primer sequence & $\begin{array}{l}\text { Cycles } \\
\mathrm{n}\end{array}$ & $\begin{array}{l}\mathrm{Tm} \\
{ }^{\circ} \mathrm{C}\end{array}$ & $\begin{array}{l}\text { Product } \\
\text { size, bp }\end{array}$ \\
\hline \multirow[t]{2}{*}{ ADAM-9 } & forward & 5'-GCTAGTTGGACTGGAGATTTGG-3' & \multirow[t]{2}{*}{30} & 57.7 & \multirow[t]{2}{*}{486} \\
\hline & reverse & 5'-TTATTACCACAGGAGGGAGCAC-3' & & 57.7 & \\
\hline \multirow[t]{2}{*}{ ADAM-10 } & forward & 5'-AATTCTGCTCCTCTCCTGGGC-3' & \multirow[t]{2}{*}{30} & 59.5 & \multirow[t]{2}{*}{299} \\
\hline & reverse & 5' -TATGTCCAGTGTAAATATGAGAGG-3' & & 54.4 & \\
\hline \multirow{2}{*}{ ADAM-12 L } & forward & 5'-CCAGAACAACTCGGCTCACT-3' & \multirow[t]{2}{*}{28} & 57.5 & \multirow[t]{2}{*}{481} \\
\hline & reverse & 5'-AGGCCTTGATCAGAAAGCAA-3' & & 53.4 & \\
\hline \multirow[t]{2}{*}{ ADAM-12 S } & forward & 5'-TCAGTGCTGCTCCTGAGAGA-3' & \multirow[t]{2}{*}{28} & 57.5 & \multirow{2}{*}{449} \\
\hline & reverse & 5'-AAGGGTTGGTGACTCTGTGG-3' & & 57.5 & \\
\hline \multirow[t]{2}{*}{ ADAM-15 } & forward & 5'-CAAATATAGGTGGCACTGAGGAG-3' & \multirow[t]{2}{*}{30} & 57.8 & \multirow[t]{2}{*}{286} \\
\hline & reverse & 5'-TAGCAGCAGTTCTCCAAAGTGTG-3' & & 57.8 & \\
\hline \multirow[t]{2}{*}{ ADAM-17 } & forward & 5'-ATGAGGCAGTCTCTCCTATTCCTGAC-3' & \multirow[t]{2}{*}{28} & 61.2 & \multirow[t]{2}{*}{456} \\
\hline & reverse & 5'-AAGTGGCTCTATGTTATATTCGGCCC-3' & & 59.6 & \\
\hline \multirow[t]{2}{*}{ ADAMTS-1 } & forward & 5'-ACGGCAGTGGTCTAAAGCAT-3' & \multirow[t]{2}{*}{30} & 55.4 & \multirow[t]{2}{*}{312} \\
\hline & reverse & 5'-AGTTCCAACATCAGCCATCC-3' & & 55.4 & \\
\hline \multirow[t]{2}{*}{ ADAMTS-2 } & forward & 5'-CTACGTCCAGAGCAGGGGTA-3' & \multirow[t]{2}{*}{30} & 59.5 & \multirow[t]{2}{*}{336} \\
\hline & reverse & 5'-GAACTCCTCCTCCTCCATCC-3' & & 59.5 & \\
\hline \multirow[t]{2}{*}{ ADAMTS-3 } & forward & 5'-TAGAAAGGGGAAACCCATCC-3' & \multirow[t]{2}{*}{30} & 55.4 & \multirow[t]{2}{*}{243} \\
\hline & reverse & 5'-CCCGTTTCATGGGCTACTAC-3' & & 57.5 & \\
\hline \multirow[t]{2}{*}{ ADAMTS-4 } & forward & 5'-TGCATCTGCCTGTGACTTTC-3' & 30 & 55.4 & 433 \\
\hline & reverse & 5'-GTTGGGCAGTCCTCAGTGTT-3' & & 57.5 & \\
\hline ADAMTS-5 & forward & 5'-GGACCTACCACGAAAGCAGA-3' & 30 & 57.5 & 411 \\
\hline & reverse & 5'-CCTCTTCCCTGTGCAGTAGC-3' & & 59.5 & \\
\hline ADAMTS-8 & forward & 5'-ACTGACATGGACGGGAATCT-3' & 30 & 55.4 & 216 \\
\hline & reverse & 5'-GAGTCCACCACATGGTCACA-3' & & 57.5 & \\
\hline ADAMTS-9 & forward & 5' -TCGCTCCACTGTTCACTGTC-3' & 28 & 57.5 & 297 \\
\hline & reverse & 5'-CCTGTTGAGGGCTCTCTCTG-3' & & 59.5 & \\
\hline ADAMTS-15 & forward & 5'-CTCCAAGCCCTGTCCTTACA-3' & 30 & 57.5 & 337 \\
\hline & reverse & 5'-CCAGATTGCAGGATCGGTAT-3' & & 55.4 & \\
\hline TIMP-1 & forward & 5' -TGGCACTCATTGCTTGTGGACG-3' & 28 & 58 & 203 \\
\hline & reverse & 5'-TCCGGAAGAAAGATGGGAGTGGGA-3' & & 58.8 & \\
\hline TIMP-2 & forward & 5' -TTCTGCACGGGGCTTTCTGCAT-3' & 28 & 57 & 528 \\
\hline & reverse & 5' -TGCTTTGGGGTTGCCGCTGAAT-3' & & 57 & \\
\hline TIMP-3 & forward & 5'-TCCTGAACCGTGTTTGTTGA-3' & 28 & 59.5 & 249 \\
\hline & reverse & 5'-CTTGACTGTGCTTGGTGGAA-3' & & 58.9 & \\
\hline$\beta$-Actin & forward & 5'-CGCCGCCAGCTCACCATGGA-3' & 30 & 59 & 611 \\
\hline & reverse & 5'-CTGTAGCCGCGCTCGGTGAG-3' & & 59 & \\
\hline
\end{tabular}

$\mathrm{Tm}=$ Melting temperature; ADAM-12 L = long isoform of ADAM-12; ADAM-12 S = short isoform of ADAM-12.

step. Using electrophoresis, the PCR products were run on $1.2 \%$ agarose gel and visualized with ethidium bromide stain.

\section{Real-Time PCR}

The mRNA expression levels of selected ADAMs, ADAMTSs and TIMPs were quantified by real-time PCR and normalized to the mRNA expression level of glyceraldehyde-3-phosphate dehydrogenase (GAPDH). Sequences of the primers used are shown in table 2. PCR reactions were run in a LightCycler 480 System (Roche) and carried out in a 96-well PCR plate format. Volumes of $17 \mu \mathrm{l}$ of LightCycler SYBR Green I Master mix (Roche), $0.5 \mu \mathrm{M}$ forward and reverse primer and $1 \mu \mathrm{l}$ of cDNA template $(20 \mu \mathrm{l}$ in total) were made and mixed well. The thermal profile of real-time PCR reactions was as follows: heating at $95^{\circ} \mathrm{C}$ for $10 \mathrm{~min}$ followed by 50 cycles of $10 \mathrm{~s}$ of denaturation at $95^{\circ} \mathrm{C}, 20 \mathrm{~s}$ at the respective annealing temperature (table 2) and $10 \mathrm{~s}$ of amplification at $72^{\circ} \mathrm{C}$. Experiments were performed in triplicate, and samples were subjected to agarose gel electrophoresis and ethidium bromide visualization to exclude nonspecific PCR. The fluorescence emitted from the SYBR green dye was read by the instrument after completion of each cycle, and the results were normalized to the mRNA expression of GAPDH. 
Table 2. The primer sequences designed for the real-time RT-PCR analysis

\begin{tabular}{|c|c|c|c|c|c|}
\hline Target gene & & Primer sequence & Cycles, n & $\mathrm{Tm},{ }^{\circ} \mathrm{C}$ & $\begin{array}{l}\text { Product } \\
\text { size, bp }\end{array}$ \\
\hline \multirow[t]{2}{*}{ ADAM-9 } & forward & 5'-TGGAACTGCAGGAATGGCA-3' & \multirow{2}{*}{50} & 58 & \multirow{2}{*}{72} \\
\hline & reverse & $5^{\prime}$-CCAAACACATTAATCCCGCC-3' & & 58 & \\
\hline \multirow[t]{2}{*}{ ADAM-10 } & forward & 5'-ACAGCCCATTCAGCAACCC-3' & \multirow[t]{2}{*}{50} & 57 & \multirow[t]{2}{*}{67} \\
\hline & reverse & 5'-GCGTCTCATGTGTCCCATTTG-3' & & 57 & \\
\hline \multirow[t]{2}{*}{ ADAM-12 L } & forward & 5'-AGGCCAGAGCCAAGGGGCTT-3' & \multirow[t]{2}{*}{50} & 60 & \multirow[t]{2}{*}{88} \\
\hline & reverse & 5'-TGGGAGCCTGCCTGCCAGTT-3' & & 60 & \\
\hline \multirow[t]{2}{*}{ ADAM-12 S } & forward & 5'-TACCACTCTGGCAGGCCCCA-3' & \multirow[t]{2}{*}{50} & 59 & \multirow[t]{2}{*}{111} \\
\hline & reverse & 5'-ACACTGGGCCCAACCCTTGC-3' & & 59 & \\
\hline \multirow[t]{2}{*}{ ADAMTS-1 } & forward & 5'-CGTCTCACCAAAGGACAGGT-3' & \multirow[t]{2}{*}{50} & 58 & \multirow[t]{2}{*}{114} \\
\hline & reverse & 5'-GAGGTGGAATCTGGGCTACA-3' & & 58 & \\
\hline \multirow[t]{2}{*}{ TIMP-1 } & forward & 5'-TCTGAAAAGGGCTTCCAGTCCCGT-3' & \multirow[t]{2}{*}{50} & 59 & \multirow[t]{2}{*}{95} \\
\hline & reverse & 5'-ATTCAGGCTATCTGGGACCGCA-3' & & 58 & \\
\hline \multirow[t]{2}{*}{ TIMP-2 } & forward & 5'-AATGAAACCGAAGCTTGGCGGC-3' & \multirow[t]{2}{*}{50} & 59 & \multirow[t]{2}{*}{92} \\
\hline & reverse & 5'-TGCTTTGGGGTTGCCGCTGAAT-3' & & 59 & \\
\hline \multirow[t]{2}{*}{ TIMP-3 } & forward & 5'-CTTTCTCCTCTGTGCCTGCT-3' & \multirow[t]{2}{*}{50} & 59 & \multirow[t]{2}{*}{86} \\
\hline & reverse & 5'-CTTGACTGTGCTTGGTGGAA-3' & & 59 & \\
\hline \multirow[t]{2}{*}{ GAPDH } & forward & 5'-CAATGACCCCTTCATTGACC-3' & \multirow[t]{2}{*}{50} & 59 & \multirow[t]{2}{*}{159} \\
\hline & reverse & 5'-TTGATTTTGGAGGGATCTCG-3' & & 59 & \\
\hline
\end{tabular}

$\mathrm{Tm}=$ Melting temperature; ADAM-12 L = long isoform of ADAM-12; ADAM-12 S = short isoform of ADAM-12.

\section{Antibodies}

Commercially available antibodies used were as follows: mouse antihuman ADAM-9 directed against the ectodomain (R\&D), goat anti-ADAM-9 polyclonal antibody directed against the $\mathrm{C}$ terminus (Santa Cruz, USA), rabbit antihuman ADAM-10 polyclonal antibody directed against the $\mathrm{C}$ terminus (Millipore, USA), rabbit antihuman ADAM-12 directed against the cytoplasmic domain (Triple Point Biologics, Forest Grove, Oreg., USA), rabbit antihuman TIMP-2 polyclonal antibody (Chemicon, Temecula, Calif., USA), mouse antihuman TIMP-3 monoclonal antibody (Abcam, Tokyo, Japan) and mouse antihuman $\beta$-actin (Abcam).

\section{Immunoblotting}

Cell cultures were washed 3 times with phosphate-buffered saline and resuspended in lysis buffer containing $50 \mathrm{~mm}$ Tris- $\mathrm{HCl}$ ( $\mathrm{pH}$ 8), $120 \mathrm{mM} \mathrm{NaCl}, 1 \mathrm{~mm}$ EDTA and 1\% protease inhibitors (Calbiochem, USA). The cell lysates were centrifuged at 15,000 $\mathrm{rpm}$ for $10 \mathrm{~min}$ at $4^{\circ} \mathrm{C}$, and the resultant supernatants were collected. Protein concentration was measured using the Bio-Rad protein assay (Hercules, Calif., USA). A total of $20 \mu \mathrm{g}$ of protein sample was resolved using $10 \%$ SDS polyacrylamide gel electrophoresis and transferred onto methanol-pretreated polyvinylidene difluoride membranes (Millipore). Membranes were blocked with $5 \%$ nonfat milk and incubated with primary antibodies overnight at $4{ }^{\circ} \mathrm{C}$. The primary antibodies were used at the following dilutions: anti-ADAM-9, 1:500; anti-ADAM-10, 1:500; antiADAM-12, 1:1,000; anti-TIMP-2, 1:1,000; anti-TIMP-3, 1:1,000, and anti- $\beta$-actin, $1: 3,000$. The membranes were then washed 3 times in Tris-buffered saline containing $0.05 \%$ Tween and incubated for $1 \mathrm{~h}$ at room temperature in horseradish peroxidase-con- jugated antirabbit or antimouse IgG at a dilution of 1:2,500. Chemiluminescent detection of horseradish peroxidase was achieved with Pierce Western blotting substrate (Thermo Scientific, USA) according to the manufacturer's instructions. The membranes were exposed to X-ray film, and the band densities were analyzed using NIH ImageJ software. Each value was normalized to the band density of the respective $\beta$-actin band.

Tissue Samples and Immunohistochemistry

Thirty-one formalin-fixed, paraffin-embedded cervical tissue blocks were obtained from the Department of Obstetrics and Gynecology of the Osaka Police Hospital. Histopathological diagnosis of each specimen was made independently by two pathologists. Tissue blocks were LSILs $(n=12)$, HSILs $(n=11)$ or invasive squamous cell carcinoma $(n=8)$. Informed consent was obtained from patients before the procedures, and the study was approved by the Osaka University review board. Tissue sections $(4-5 \mu \mathrm{m})$ from representative paraffin blocks were deparaffinized in xylene and rehydrated in graded ethanol. The sections were subjected to heating in target retrieval buffer for $20 \mathrm{~min}$. Endogenous peroxidases were blocked using 10\% hydrogen peroxide for $15 \mathrm{~min}$. Further blocking was carried out by incubating the sections with $5 \%$ bovine serum albumin for $30 \mathrm{~min}$. The slides were then incubated with the primary antibody at $4^{\circ} \mathrm{C}$ in a moist chamber overnight. The primary antibodies were anti-ADAM-9 (1:50; R\&D), antiADAM-10 (1:100; Millipore) and anti-TIMP-3 (1:100; Abcam). The slides were then incubated with specific secondary antibody at a dilution of 1:100 for $30 \mathrm{~min}$ at room temperature. The sections were incubated with streptavidin (Chemicon) at a dilution of 1:100 for $30 \mathrm{~min}$. The sections were treated with 3,3'-diamino- 
benzidine as a chromogen, and finally slides were counterstained with hematoxylin. Negative controls were included, with the omission of primary antibodies.

\section{Evaluation of Immunoreactivity}

The immunoreactivity was judged according to the distribution of staining (membranous, cytoplasmic and nuclear) and semiquantitative assessment of immunoreactivity, i.e. brown nuclear and cytoplasmic reactivity. A simplified scoring system was developed by calculating the percentage of immunoreactive cells. For each slide, nearly 3,000 cells were assessed for expression of a given antigen. The immunoreactivity was scored as negative (no reactive cells), weak ( $<10 \%$ reactive cells), moderate $(11-50 \%)$ or strong (50-100\%).

\section{Statistical Analysis}

Data from densimetric studies of multiple experiments were calculated for graphical depiction and statistical analysis. Student's t test was used to construct 95\% confidence intervals for the differences in the various cell lines. ADAM expression in normal cervical tissue, LSILs, HSILs and cervical cancer was compared using analysis of variance. Statistical significance was defined by a $\mathrm{p}$ value of $<0.05$.

\section{Results}

\section{Differential Expression of ADAM and ADAMTS} mRNAs

To determine the expression of ADAMs and ADAMTSs in cervical cells, and to investigate their aberrant expression (if any) during cervical carcinogenesis, we performed conventional PCR analysis using an in vitro multistep carcinogenesis model of cervical cancer and human squamous cervical cancer cell lines.

ADAMs with an active catalytic domain, such as ADAM-9, -10, -12, -15 and -17, together with ADAMTS-1, $-2,-3,-4,-5,-8,-9$ and -15 , were evaluated in our study. Levels of ADAM-9, -10 and -12 mRNAs were gradually upregulated in the oncogenically modified keratinocytes and in the cancer cell lines compared to the normal keratinocytes. ADAM-15 mRNA was detected only in normal keratinocytes and in the cancer cell lines (fig. 1).

Among the ADAMTSs tested, only ADAMTS-1 showed expression in carcinogenesis steps and in cancer cell lines (fig. 1). ADAMTS-3 mRNA was expressed in all the cancer cell lines, with no expression in the oncogenically modified cells. ADAMTS-2 mRNA was not detected in either of the groups. Some ADAMTSs were expressed sporadically in some cervical cancer cell lines (fig. 1).

To obtain more sensitive measurement, we performed real-time quantitative RT-PCR analysis using mRNAs from oncogenically modified cells and cervical cancer cell lines.

Expression of ADAM/ADAMTS Proteins in Cervical Carcinogenesis

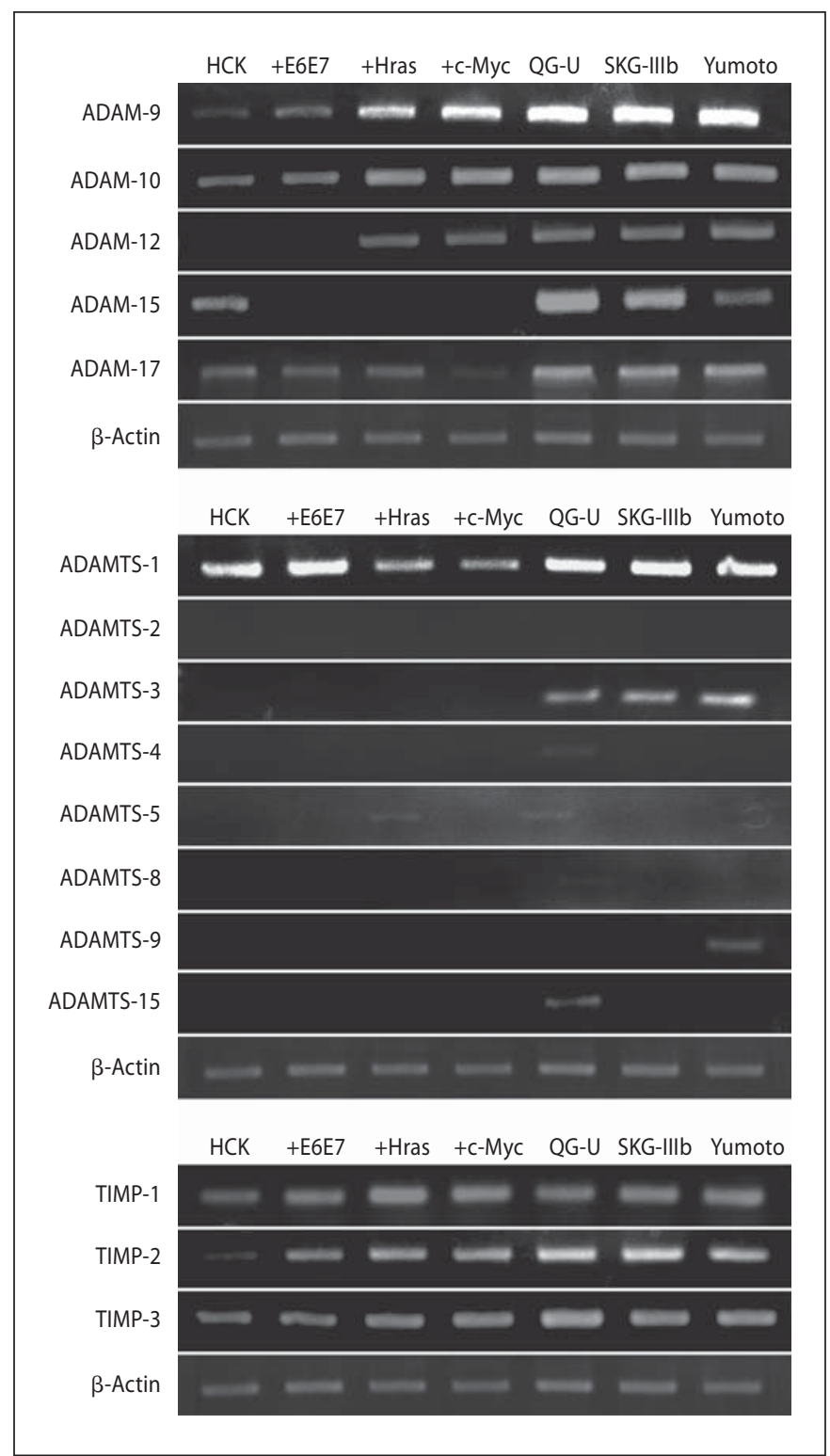

Fig. 1. RT-PCR analysis of ADAMs, ADAMTSs and TIMPs mRNA expression in normal keratinocytes ( $\mathrm{HCK}=$ control cells), oncogenically modified keratinocytes $(+\mathrm{E} 6 \mathrm{E} 7=\mathrm{LSILs} ;+\mathrm{Hras}=$ HSILs; $+c-M y c=$ invasive lesions) and squamous-type cervical cancer cell lines (QG-U, SKG-IIIb and Yumoto). The products were separated by agarose gel electrophoresis and stained with ethidium bromide.

The changes in ADAMs mRNA levels were normalized for levels of GAPDH mRNA in the same PCR. Alternative splicing of the ADAM- 12 gene produces 2 isoforms, 1 long and 1 short; therefore, 2 pairs of primers were designed. A two-fold increase (a value of 2) or decrease (a value of 1) was considered target gene mRNA 


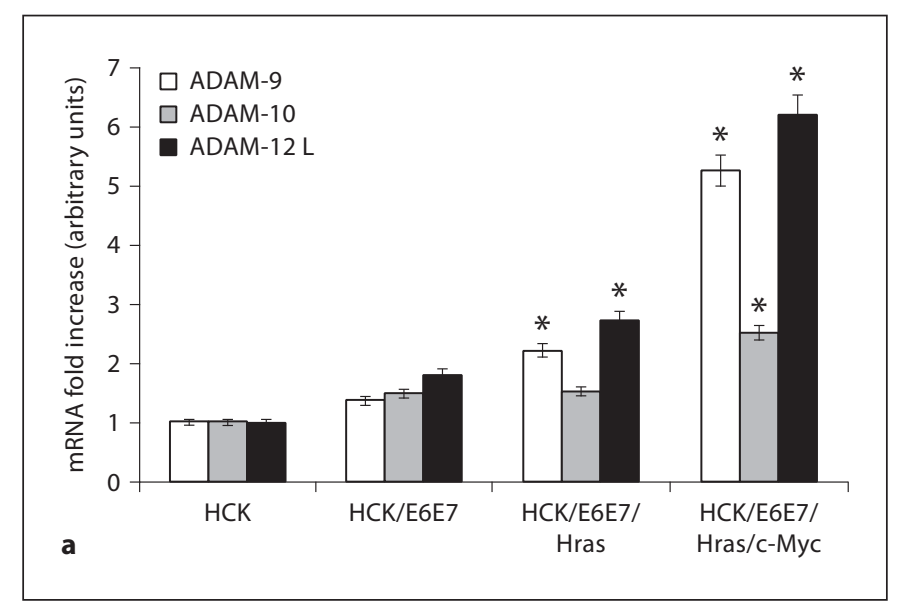

Fig. 2. Quantitative RT-PCR analysis of ADAM-9, ADAM-10 and the long form of ADAM-12 (ADAM-12 L) (a) and TIMP-1, -2 and -3 mRNAs (b) in oncogenically modified keratinocytes (HCK/ E6E7 = LSILs; HCK/E6E7/Hras = HSILs; HCK $/$ E6E7/Hras $/ \mathrm{c}-$

upregulation or downregulation, respectively. The expression of ADAM-9 and the long form of ADAM-12 mRNA was significantly elevated in E6E7/Hras and E6E7/Hras/c-Myc cells compared to normal and E6E7 cells $(\mathrm{p}<0.05$; fig. $2 \mathrm{a}$ ). The expression of ADAM-10 mRNA was significantly upregulated in E6E7/Hras/cMyc cells compared to the rest of the cells $(\mathrm{p}<0.05$; fig. 2a). Quantitative PCR of ADAM-15, ADAM-17 and ADAMTS-1 did not show significant modulation.

\section{Immunoblotting and Quantification of ADAMs}

Immunoblotting was essential to corroborate the results obtained by quantitative RT-PCR analysis and to study the protein status. Quantitative image analysis, using $\beta$-actin as an internal housekeeping gene, was used to correct for protein loading between the control and test lanes in each experiment.

Immunoblotting of ADAM-9 protein showed 3 different bands, migrating with molecular masses of 114,85 and $50 \mathrm{kDa}$, which represent the precursor, mature and processed forms of ADAM-9, respectively (fig. 3a, b). The ADAM-9 precursor form (114 $\mathrm{kDa})$ was expressed in E6E7/Hras $\pm c$-Myc-transduced keratinocytes and undetectable in E6E7-transduced and normal cervical keratinocytes. There was no significant difference in the frequency of expression of the ADAM-9 mature form (85 $\mathrm{kDa}$ ) among the oncogenically modified cells. Modest upregulation of expression of the processed form (50 $\mathrm{kDa}$ ) could be noticed as cells acquired viral E6E7 and progressed into tumorigenesis (fig. 3a). Similarly, cervical

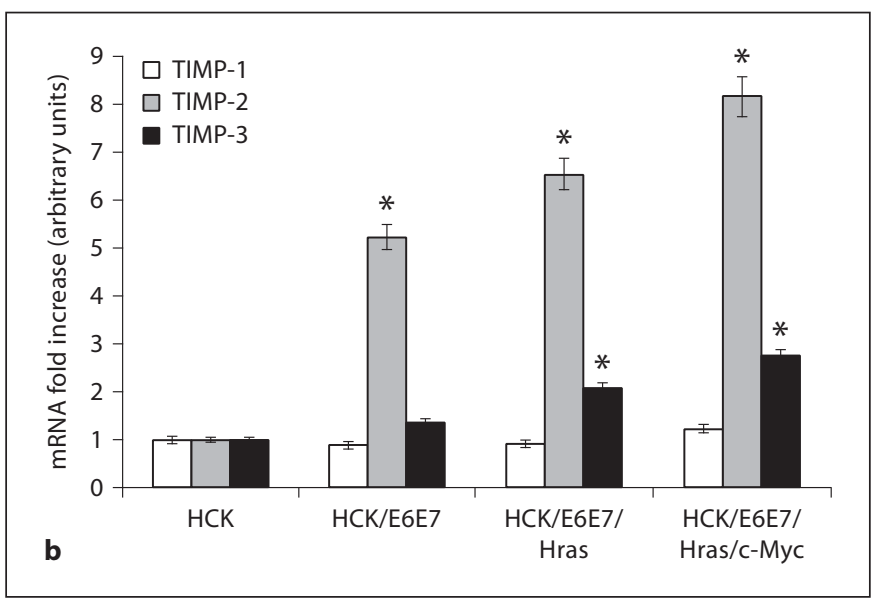

Myc = invasive lesions) compared to control cells (HCK). Values for ADAMs and TIMPs in the different oncogenic stages were normalized relative to the expression levels of normal keratinocytes and normalized to the housekeeping gene (GAPDH). ${ }^{*} \mathrm{p}<0.05$. cancer cell lines (QG-U and Yumoto) showed significant upregulation of the processed form of ADAM-9 compared to normal cells ( $\mathrm{p}<0.05$; fig. $3 \mathrm{~b})$.

Analysis of ADAM-10 revealed a band corresponding to a relative mass of approximately $85 \mathrm{kDa}$. ADAM-10 showed upregulation as keratinocytes acquire viral oncoproteins and genetic alteration(s) (fig. 3c). Densitometry analysis showed that the relative protein concentration was most prominent in the E6E7/Hras \pm c-Myc-transduced keratinocytes compared to normal cervical keratinocytes $(\mathrm{p}<0.05)$. Similarly, the level of ADAM-10 protein was upregulated in QG-U cancer cells compared to the normal cervical keratinocytes (fig. 3d).

Western blotting of ADAM-12 revealed a band corresponding to a molecular weight of about $84 \mathrm{kDa}$. Analysis showed that ADAM-12 was not expressed in normal cervical cells, but expression was noticed in E6E7 and E6E7/ Hras \pm c-Myc-transformed cells. Similarly, ADAM-12 protein was expressed in all the cervical cancer cell lines (fig. 3e, f).

\section{Expression of TIMPs: The Physiological Inhibitors of ADAMs}

mRNA levels of TIMP-1, -2 and -3 were analyzed by semiquantitative RT-PCR (fig. 1) and real-time PCR. Interestingly, quantitative RT-PCR showed that the transcript levels of TIMP-2 and TIMP-3, but not TIMP1 , were upregulated as cervical cells became carcinogenic compared with normal keratinocytes $(\mathrm{p}<0.05$; fig. 2b). 
Fig. 3. Immunoblotting of ADAM-9, -10 and -12 . Whole-cell lysates from normal keratinocytes $(\mathrm{HCK}=$ control cells), oncogenically modified keratinocytes (+E6E7 = LSILs; +Hras = HSILs; +c-Myc = invasive lesions) and 3 cervical cancer cell lines (QG-U, SKG-IIIb and Yumoto) were analyzed using specific antibodies. $\beta$-actin served as a loading control. a, b Immunoblotting of ADAM-9 shows 3 distinctive bands: precursor, mature and processed at 114,85 and $50 \mathrm{kDa}$, respectively. c, d Immunoblotting of ADAM-10 (band at approx. $85 \mathrm{kDa}$ ). e, f Immunoblotting of ADAM-12 protein (band at approx. 84 $\mathrm{kDa}$ ). The densitometric ratios of the respective ADAM to $\beta$-actin are shown in the lower panels. These results are representative of 3 independent experiments. $\mathrm{AU}=$ Arbitrary units. ${ }^{*} \mathrm{p}<0.05$.
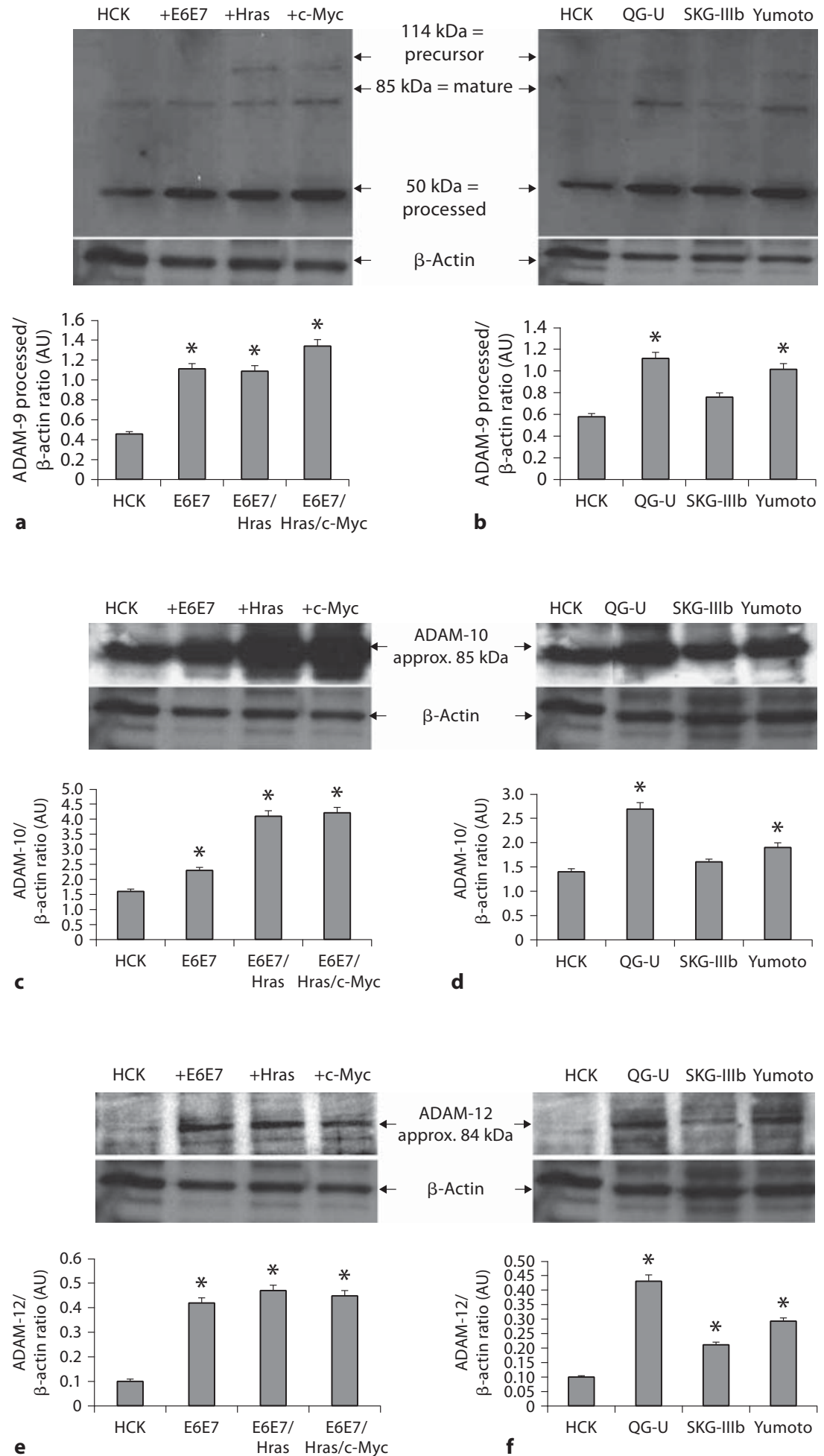
Fig. 4. Immunoblotting of TIMP-2 and TIMP-3. Whole-cell lysates from normal keratinocytes $(\mathrm{HCK}=$ control cells), oncogenically modified keratinocytes $(+\mathrm{E} 6 \mathrm{E} 7=$ LSILs; +Hras = HSILs; +c-Myc = invasive lesions) and 3 cervical cancer cell lines (QG-U, SKG-IIIb and Yumoto) were analyzed using specific antibodies. $\beta$-actin served as a loading control. a, b Immunoblotting of TIMP-2 protein (band at 21 $\mathrm{kDa})$. c, d Immunoblotting of TIMP-3 showed bands at 27 and $24 \mathrm{kDa}$, which represent the glycosylated and nonglycosylated forms, respectively. The densitometric ratios of the respective TIMP to $\beta$-actin are shown in the lower panels. These results are representative of 3 independent experiments. AU $=$ Arbitrary units. ${ }^{*} \mathrm{p}<$ 0.05 .
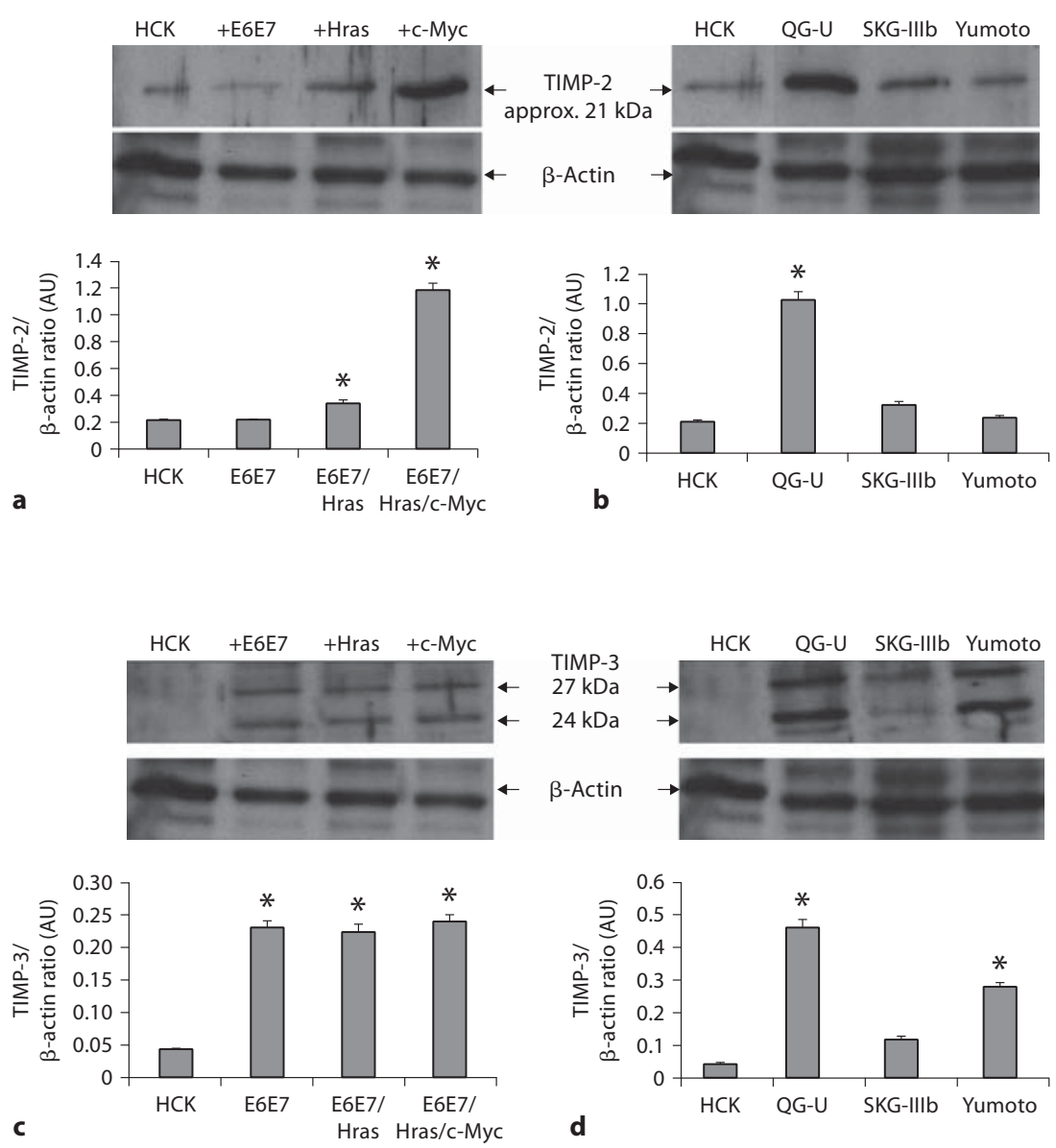

Immunoblotting of TIMP-2 $(21 \mathrm{kDa})$ showed overexpression in E6E7/Hras/c-Myc cells compared to the other cells ( $p<0.05$; fig. $4 \mathrm{a})$ ). Similarly, the level of TIMP-2 was higher in the QG-U cervical cancer cell line in comparison to the normal keratinocytes ( $\mathrm{p}<0.05$; fig. $4 \mathrm{~b}$ ). Expression of TIMP-3 could be detected at 24 and $27 \mathrm{kDa}$, which represent the nonglycosylated and the glycosylated forms, respectively. Normal keratinocytes showed faint bands at the expected size that become more distinctive and overexpressed in oncogenically modified keratinocytes (fig. 4c). Similarly, cervical cancer cell lines (QG-U and Yumoto) showed upregulated TIMP-3 compared to normal keratinocytes (fig. $4 \mathrm{~d}$ ).

\section{Immunohistochemistry}

To verify the in vitro findings, we stained for ADAM9, ADAM-10 and TIMP-3 using cervical preinvasive and invasive cervical tissues. Immunostaining was able to determine protein localization and distribution.

\section{Immunostaining of ADAM-9}

Immunostaining showed that ADAM-9 was weakly expressed in squamous epithelial cells from normal cervical tissues and localized to the superficial epithelial layers with a membranous staining pattern (fig. 5a, b). LSILs showed moderate immunostaining for ADAM-9 that involved the superficial layers in addition to the parabasal layers (fig. 5c, d). Strong immunoreactivity was noticed in most HSILs, with intense staining confined to the basal layer. In HSILs, both cytoplasmic and membranous staining was observed (fig. 5e, f). Squamous cell carcinoma revealed intense immunostaining for ADAM-9, with nuclear and cytoplasmic distribution (fig. $5 \mathrm{~g}, \mathrm{~h}$ ). Statistical tests showed that expression of 

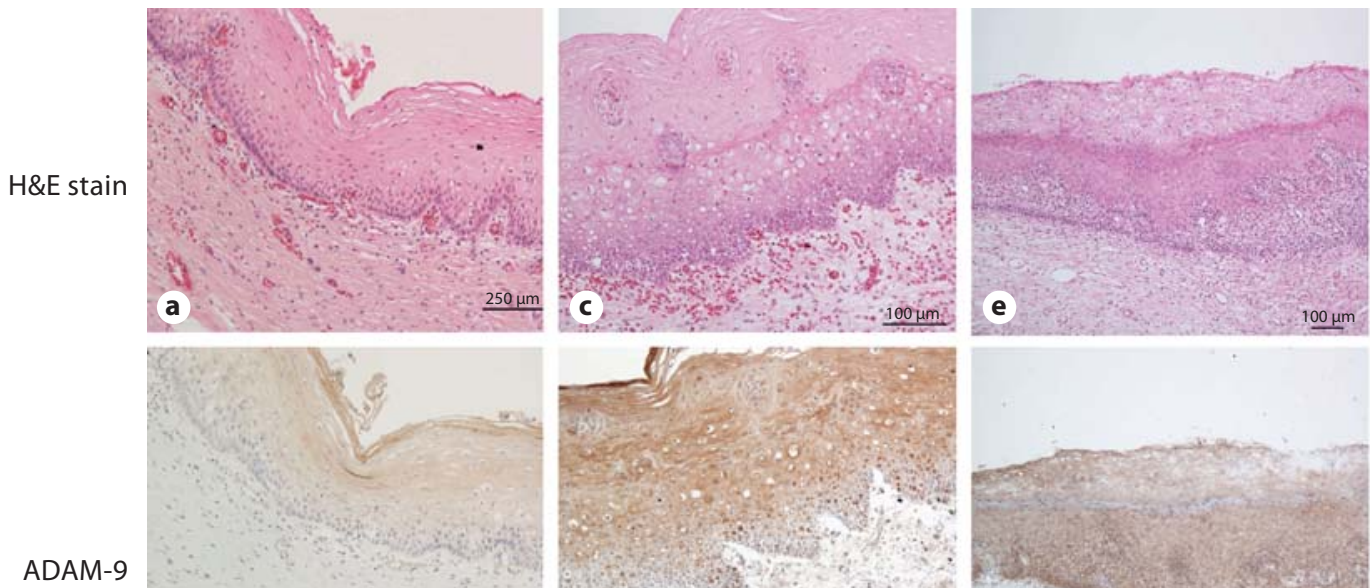

b
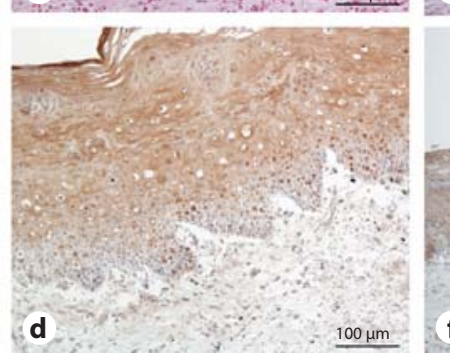
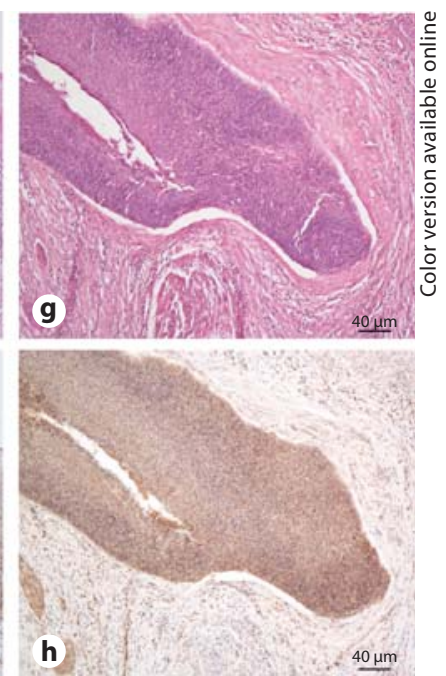

Fig. 5. Immunohistochemistry of ADAM-9 with hematoxylin (H\&E) counterstaining. Expression of ADAM-9 increased with increasing severity of dysplasia in cervical squamous epithelia. a, b ADAM-9 expression is absent or weak in benign cervical epithelia. $\times 40$. c, d In the LSIL, the expression of ADAM-9 is evi-

dent in the superficial layers with some scattering in the basal layer. $\times 100$. e, $\mathbf{f}$ In the HSIL, ADAM- 9 immunostaining is present in the full thickness with strong intensity in the basal layer. $\times 40 . \mathbf{g}, \mathbf{h}$ Prominent expression of ADAM-9 is noted in the invasive cancer cells. $\times 100$.
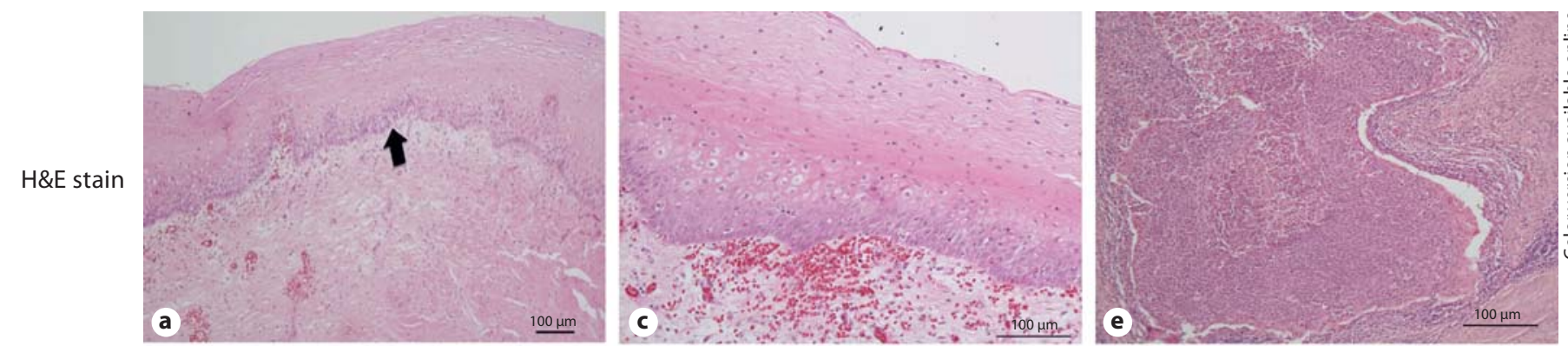

ADAM-10
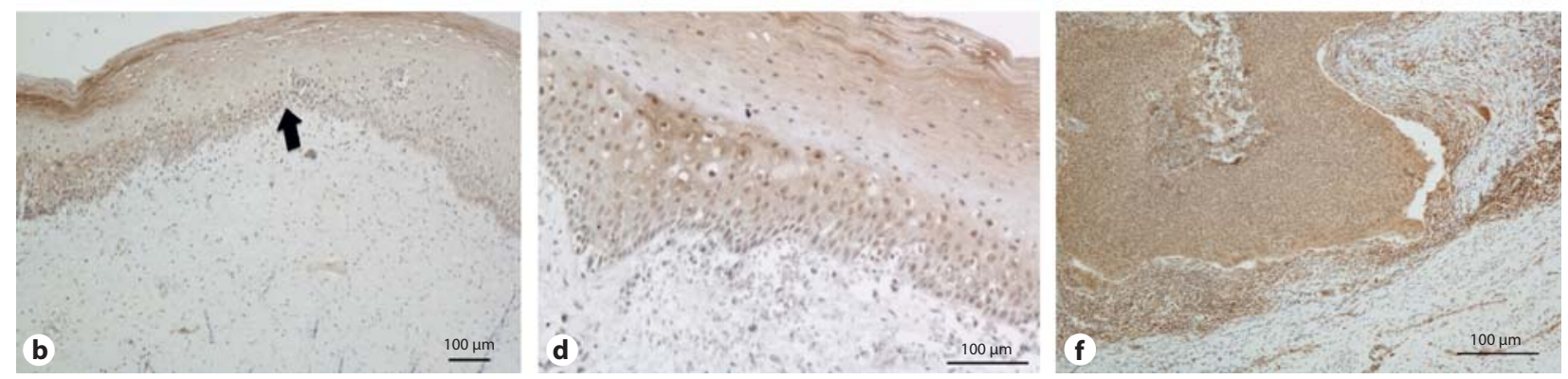

Fig. 6. Immunohistochemical detection of ADAM-10 with hematoxylin (H\&E) counterstaining. a, b Note the transitional zone (arrow) between the normal epithelium (right) and the LSIL (left). $\times 40$. ADAM-10 expression showed increased immunoreactivity as lesions became dysplastic (b). c, d In the LSIL, the expression of ADAM-10 is noticed in the basal and some parabasal layers. $\times 100$. e, $\mathbf{f}$ Strong expression of ADAM-10 is noticed in the cancer nests in invasive cancer. $\times 100$. 

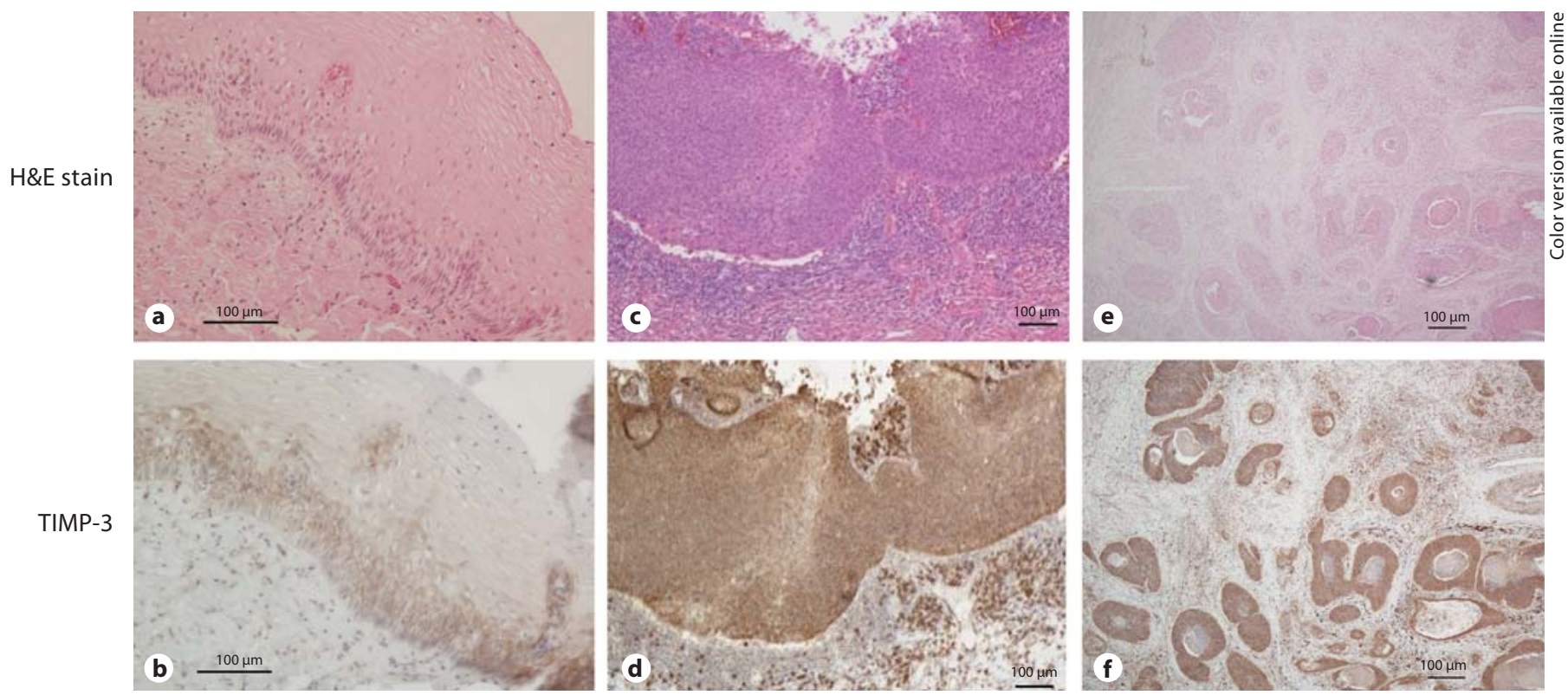

Fig. 7. Immunohistochemistry of TIMP-3 with hematoxylin (H\&E) counterstaining. a, b Weak immunostaining of TIMP3 is noted in the LSIL. $\times 100$. c, d TIMP-3 showed moderate staining in the HSIL. $\times 40$. e, f Strong immunoreactivity of TIMP-3 can be noted in the cancer nests in invasive cancer. $\times 40$.

ADAM-9 is significantly upregulated in HSILs and invasive cancer compared to benign squamous epithelium $(\mathrm{p}<0.05)$.

\section{Immunostaining of ADAM-10}

Normal cervical tissue showed absent or weak staining for ADAM-10. Dysplastic cells showed reactivity to ADAM-10 antibody (fig. 6a, b). The staining intensity of LSILs was moderate and was mainly in the basal and parabasal layers (fig. $6 \mathrm{c}, \mathrm{d}$ ). Invasive cancer showed strong immunostaining for ADAM-10 (fig. 6e, f). ADAM-10 expression was significantly upregulated in invasive cancer compared to the preinvasive lesions $(\mathrm{p}<$ 0.05).

\section{Immunostaining of TIMP-3}

Scattered immunoreactivity for TIMP-3 could be detected in the normal cervical mucosa. LSILs showed weak immunoreactivity confined to the basal layer (fig. 7a, b). Moderate to strong immunostaining for TIMP-3 was noticed in HSILs (fig. 7c, d), with diffuse strong immunoreactivity in invasive cancer (fig. 7e, f). TIMP-3 staining showed both nuclear and cytoplasmic patterns. Expression of TIMP-3 in squamous cell carcinoma and HSILs was significantly upregulated compared to LSILs and normal epithelium $(\mathrm{p}<0.05)$.

\section{Discussion}

This study provides novel evidence for dysregulated expression of disintegrin proteins in squamous cell carcinoma of the uterine cervix and its precursor lesions. The mRNA level of ADAM-9, as well as the processed form of ADAM-9 protein (approx. $50 \mathrm{kDa}$ ), was found to be significantly upregulated when cells become oncogenically mutated compared to only virally infected cells. It was shown that a processed, alternatively spliced form of ADAM-9 is necessary for invasion through its binding to $\alpha 6 \beta 4$ and $\alpha 2 \beta 1$ integrins of colon cancer cells [30]. This work also demonstrates that the frequency and intensity of ADAM-9 expression, as assessed by immunohistochemical analysis, increases within HSILs and invasive carcinoma relative to LSILs and normal cells. Our immunohistochemical data are in accordance with a previous report indicating increased ADAM-9 immunoreactivity in both cervical intraepithelial neoplasia grade 3 (CIN3) and invasive tumors of the uterine cervix [31]. Physiologically, it was shown that mouse ADAM-9 is not essential for normal development or adult homeostasis [32]. However, human ADAM-9 was found to regulate keratinocyte migration through interaction with $\beta 1$ integrins and modulation of MMP synthesis [33]. The expression of ADAM-9 was previously reported to be upregulated at 
the mRNA and/or protein level in various solid cancers [34-36]. Furthermore, ADAM-9 overexpression in lung tumor is correlated with brain metastasis [37]. Hence, the biological role of ADAM-9 in cancer could relate to its ability to bind integrins and to degrade extracellular matrix, which promote cell invasion [30]. In addition, blocking ADAM-9 in gastric cancer resulted in inhibition of cell growth of gastric cancer cell lines [38].

Our study describes, for the first time, the expression and regulation of ADAM-10 during cervical carcinogenesis. ADAM-10 was upregulated in oncogenically mutated keratinocytes compared to normal or virally infected cells. The result was confirmed by examining the immunoreactivity of ADAM-10 in preinvasive and invasive cervical tissues. It was found that ADAM-10 could cleave several extracellular matrix components, such as collagen IV of the basement membrane [39], and can also increase the motility of keratinocytes through its ability to shed soluble basement membrane collagen XVII (BPAG2), which supports interactions between the basal cells and the underlying basement membrane [40]. Aberrant expression of collagen XVII in invasive cervical lesions has been investigated elsewhere [41]. However, the relationship between collagen XVII and ADAM-10 in cervical lesions requires further study. Overexpression of ADAM10 was also found in prostate and oral cancers [42, 43].

This work describes the novel expression of ADAM-12 in cervical carcinogenesis. Interestingly, normal keratinocytes did not express ADAM-12, while virally infected and oncogenically modified keratinocytes showed ADAM-12 expression. As shown by quantitative RTPCR, the long form of ADAM-12, but not the short form, was only found to be upregulated during cervical carcinogenesis. This finding is similar to the expression of ADAM-12 in lung and bladder cancers $[44,45]$. Experimental studies showed that the ADAM-12 level is associated with cancer through degradation of extracellular matrix, as well as regulation of cell proliferation and apoptosis [46, 47]. Earlier studies showed that the cyto- plasmic parts of ADAM-12 and ADAM-15 interact with Src homology 3 domain to exert their actions $[48,49]$.

Taking these findings together, we can conclude that the upregulation of ADAM-12 by invasive cervical cells, compared to absent expression in normal cells, plays an important role in the steps of cervical carcinogenesis.

TIMPs, endogenous regulators of MMPs, can selectively inhibit several ADAMs and ADAMTSs [48]. Therefore, TIMPs can regulate the degradation of extracellular matrix and control cell ligand shedding. Immunoblotting assays showed upregulation of TIMP-2 and TIMP-3 during the course of cervical carcinogenesis, with the highest expression in the invasive phenotype. Biologically, TIMP-2 can selectively inhibit ADAM-12, while TIMP3 has a wide range of inhibitory effects against ADAMs, including ADAM-10 and ADAM-12 [50, 51].

The expression of TIMPs, in relation to ADAMs, was reported to be dysregulated during several pathological conditions [52]. The aberrant expression of TIMP-2 and -3 in cervical lesions might be biologically relevant, but not exclusively, to the activities of the investigated ADAMs. Based on quantitative RT-PCR results, the selected ADAMTS members might have no role during cervical neoplasia, such as ADAMs do.

In summary, the dysregulated expression of several ADAMs during cervical carcinogenesis can be best noticed when cervical cells acquire genetic alteration(s), as infection with HPV alone, as seen in LSILs, is not enough to provoke ADAM expression significantly. However, synergistic effects of viral oncoproteins and genetic change(s) cannot be ruled out. We can conclude that the expression of several ADAMs, as well as their endogenous regulators, is dysregulated in cervical neoplasia. ADAM-9, -10 and -12 are overexpressed in HSILs and cancerous cells, suggesting that these proteins could play a crucial role in the pathogenesis of cervical carcinoma. The exact mechanism of action requires further studies to determine the biological effects of these proteins during the cascades of cervical neoplasia.

\section{References}

$>1$ Thun MJ, DeLancey JO, Center MM, Jemal A, Ward EM: The global burden of cancer: priorities for prevention. Carcinogenesis 2010;31:100-110.

2 Stoler MH: Human papillomaviruses and cervical neoplasia: a model for carcinogenesis. Int J Gynecol Pathol 2000;19:16-28.

Expression of ADAM/ADAMTS Proteins in Cervical Carcinogenesis
-3 Münger K, Baldwin A, Edwards KM, Hayakawa $H$, Nguyen CL, Owens M, Grace M, Huh K: Mechanisms of human papillomavirus-induced oncogenesis. J Virol 2004;78: 11451-11460.

4 zur Hausen H: Papillomaviruses and cancer: from basic studies to clinical application. Nat Rev Cancer 2002;2:342-350. $\checkmark 5$ Wolfsberg TG, Primakoff P, Myles DG, White JM: ADAM, a novel family of membrane proteins containing A Disintegrin And Metalloprotease domain: multipotential functions in cell-cell and cell-matrix interactions. J Cell Biol 1995;131:275-278. 
-6 Jones GC, Riley GP: ADAMTS proteinases: a multi-domain, multi-functional family with roles in extracellular matrix turnover and arthritis. Arthritis Res Ther 2005;7:160-169.

$\checkmark 7$ Van Goor H, Melenhorst WB, Turner AJ, Holgate ST: Adamalysins in biology and disease. J Pathol 2009;219:277-286.

$\checkmark 8$ Higuchi Y, Yasui A, Matsuura K, Yamamoto S: CD156 transgenic mice. Different responses between inflammatory types. Pathobiology 2002;70:47-54.

-9 Shiomi T, Lemaître V, D’Armiento J, Okada Y: Matrix metalloproteinases, a disintegrin and metalloproteinases, and a disintegrin and metalloproteinases with thrombospondin motifs in non-neoplastic diseases. Pathol Int 2010;60:477-496.

- 10 Eto K, Huet C, Tarui T, Kupriyanov S, Liu HZ, Puzon-McLaughlin W, Zhang XP, Sheppard D, Engvall E, Takada Y: Functional classification of ADAMs based on a conserved motif for binding to integrin alpha 9 beta1: implications for sperm-egg binding and other cell interactions. J Biol Chem 2002; 277:17804-17810

11 Yang P, Baker KA, Hagg T: The ADAMs family: coordinators of nervous system development, plasticity and repair. Prog Neurobiol 2006;79:73-94.

12 Gilpin BJ, Loechel F, Mattei MG, Engvall E, Albrechtsen R, Wewer UM: A novel, secreted form of human ADAM 12 (meltrin alpha) provokes myogenesis in vivo. J Biol Chem 1998;273:157-166.

$\checkmark 13$ Kawaguchi N, Xu X, Tajima R, Kronqvist P, Sundberg C, Loechel F, Albrechtsen R, Wewer UM: ADAM 12 protease induces adipogenesis in transgenic mice. Am J Pathol 2002;160:1895-1903.

-14 Duffy MJ, McKiernan E, O’Donovan N, McGowan PM: Role of ADAMs in cancer formation and progression. Clin Cancer Res 2009;15:1140-1144.

15 Mochizuki S, Okada Y: ADAMs in cancer cell proliferation and progression. Cancer Sci 2007;98:621-628.

$\checkmark 16$ Apte SS: A disintegrin-like and metalloprotease (reprolysin-type) with thrombospondin type 1 motif (ADAMTS) superfamily: functions and mechanisms. J Biol Chem 2009;284:31493-31497.

-17 Liu YJ, Xu Y, Yu Q: Full-length ADAMTS-1 and the ADAMTS-1 fragments display proand antimetastatic activity, respectively. Oncogene 2006;25:2452-2467.

- 18 Rocks N, Paulissen G, El Hour M, Quesada F, Crahay C, Gueders M, Foidart JM, Noel A, Cataldo D: Emerging roles of ADAM and ADAMTS metalloproteinases in cancer. Biochimie 2008;90:369-379.

-19 Murphy G: The ADAMs: signalling scissors in the tumour microenvironment. Nat Rev Cancer 2008;8:929-941.
20 Maskos K, Fernandez-Catalan C, Huber R, Bourenkov GP, Bartunik H, Ellestad GA, Reddy P, Wolfson MF, Rauch CT, Castner BJ Davis R, Clarke HR, Petersen M, Fitzner JN, Cerretti DP, March CJ, Paxton RJ, Black RA, Bode W: Crystal structure of the catalytic domain of human tumor necrosis factor-alpha-converting enzyme. Proc Natl Acad Sci USA 1998;95:3408-3412.

-21 Brew K, Dinakarpandian D, Nagase H: Tissue inhibitors of metalloproteinases: evolution, structure and function. Biochim Biophys Acta 2000;1477:267-283.

22 Amour A, Knight CG, Webster A, Slocombe PM, Stephens PE, Knäuper V, Docherty AJ Murphy G: The in vitro activity of ADAM-10 is inhibited by TIMP-1 and TIMP-3. FEBS Lett 2000;473:275-279.

23 Kashiwagi M, Tortorella M, Nagase H, Brew $\mathrm{K}$ : TIMP-3 is a potent inhibitor of aggrecanase 1 (ADAM-TS4) and aggrecanase 2 (ADAM-TS5). J Biol Chem 2001;276:1250112504.

24 Hanahan D, Weinberg RA: The hallmarks of cancer. Cell 2000;100:57-70.

25 Sheu BC, Lien HC, Ho HN, Lin HH, Chow SN, Huang SC, Hsu SM: Increased expression and activation of gelatinolytic matrix metalloproteinases is associated with the progression and recurrence of human cervical cancer. Cancer Res 2003;63:6537-6542.

26 Libra M, Scalisi A, Vella N, Clementi S, Sorio R, Stivala F, Spandidos DA, Mazzarino C Uterine cervical carcinoma: role of matrix metalloproteinases. Int J Oncol 2009;34: 897-903.

27 Ueda M, Terai Y, Yamashita Y, Kumagai K, Ueki K, Yamaguchi H, Akise D, Hung YC, Ueki M: Correlation between vascular endothelial growth factor-C expression and invasion phenotype in cervical carcinomas. Int J Cancer 2002;98:335-343.

28 Mitsuhashi A, Tanaka H, Tanaka N, Sugita M, Shirasawa H, Tokita H, Eda H, Sekiya S Establishment and characterization of a new HPV-negative squamous cell carcinoma cell line (Yumoto) from the human uterine cervix. Gynecol Oncol 1998;70:339-347.

29 Narisawa-Saito M, Yoshimatsu Y, Ohno S, Yugawa T, Egawa N, Fujita M, Hirohashi S, Kiyono T: An in vitro multistep carcinogenesis model for human cervical cancer. Cancer Res 2008;68:5699-5705.

30 Mazzocca A, Coppari R, De Franco R, Cho JY, Libermann TA, Pinzani M, Toker A: A secreted form of ADAM9 promotes carcinoma invasion through tumor-stromal interactions. Cancer Res 2005;65:4728-4738.

-31 Zubel A, Flechtenmacher C, Edler L, Alonso A: Expression of ADAM9 in CIN3 lesions and squamous cell carcinomas of the cervix. Gynecol Oncol 2009;114:332-336.
32 Weskamp G, Cai H, Brodie TA, Higashyama S, Manova K, Ludwig T, Blobel CP: Mice lacking the metalloprotease-disintegrin MDC9 (ADAM9) have no evident major abnormalities during development or adult life. Mol Cell Biol 2002;22:1537-1544.

33 Zigrino P, Steiger J, Fox JW, Löffek S, Schild A, Nischt R, Mauch C: Role of ADAM-9 disintegrin-cysteine-rich domains in human keratinocyte migration. J Biol Chem 2007; 282:30785-30793.

-34 O’Shea C, McKie N, Buggy Y, Duggan C, Hill AD, McDermott E, O’Higgins N, Duffy MJ: Expression of ADAM-9 mRNA and protein in human breast cancer. Int J Cancer 2003; 105:754-761

>35 Zigrino P, Mauch C, Fox JW, Nischt R: Adam-9 expression and regulation in human skin melanoma and melanoma cell lines. Int J Cancer 2005;116:853-859.

36 Peduto L, Reuter VE, Shaffer DR, Scher HI, Blobel CP: Critical function for ADAM9 in mouse prostate cancer. Cancer Res 2005;65: 9312-9319.

>37 Shintani Y, Higashiyama S, Ohta M, Hirabayashi $H$, Yamamoto $S$, Yoshimasu $T$, Matsuda H, Matsuura N: Overexpression of ADAM9 in non-small cell lung cancer correlates with brain metastasis. Cancer Res 2004;64:4190-4196.

38 Carl-McGrath S, Lendeckel U, Ebert M, Roessner A, Rocken C: The disintegrin-metalloproteinases ADAM9, ADAM12, and ADAM15 are upregulated in gastric cancer. Int J Oncol 2005;26:17-24.

-39 Millichip M, Dallas D, Wu E, Dale S, McKie $\mathrm{N}$ : The metallo-disintegrin ADAM10 (MADM) from bovine kidney has type IV collagenase activity in vitro. Biochem Biophys Res Commun 1998;245:594-598.

40 Franzke CW, Tasanen K, Schacke H, Zhou Z, Tryggvason K, Mauch C, Zigrino P, Sunnarborg S, Lee DC, Fahrenholz F, Bruckner-Tuderman L: Transmembrane collagen XVII, an epithelial adhesion protein, is shed from the cell surface by ADAMs. EMBO J 2002;21: 5026-5035.

-41 Yamada T, Endo R, Tsukagoshi K, Fujita S, Honda K, Kinoshita M, Hasebe T, Hirohashi S: Aberrant expression of a hemidesmosomal protein, bullous pemphigoid antigen 2, in human squamous cell carcinoma. Lab Invest 1996;75:589-600.

-42 McCulloch DR, Akl P, Samaratunga H, Herington AC, Odorico DM: Expression of the disintegrin metalloprotease, ADAM-10, in prostate cancer and its regulation by dihydrotestosterone, insulin-like growth factor I, and epidermal growth factor in the prostate cancer cell model LNCaP. Clin Cancer Res 2004;10:314-323

-43 Ko SY, Lin SC, Wong YK, Liu CJ, Chang KW, Liu TY: Increase of disintergin metalloprotease 10 (ADAM10) expression in oral squamous cell carcinoma. Cancer Lett 2007;245: 33-43. 
-44 Rocks N, Paulissen G, Quesada Calvo F, Polette M, Gueders M, Munaut C, Foidart JM, Noel A, Birembaut P, Cataldo D: Expression of a disintegrin and metalloprotease (ADAM and ADAMTS) enzymes in human nonsmall-cell lung carcinomas (NSCLC). Br J Cancer 2006;94:724-730.

-45 Fröhlich C, Albrechtsen R, Dyrskjøt L, Rudkjaer L, Ørntoft TF, Wewer UM: Molecular profiling of ADAM12 in human bladder cancer. Clin Cancer Res 2006;12:7359-7368.

-46 Roy R, Wewer UM, Zurakowski D, Pories SE, Moses MA: ADAM 12 cleaves extracellular matrix proteins and correlates with cancer status and stage. J Biol Chem 2004;279: 51323-51330.
7 Rocks N, Estrella C, Paulissen G, QuesadaCalvo F, Gilles C, Guéders MM, Crahay C, Foidart JM, Gosset P, Noel A, Cataldo DD: The metalloproteinase ADAM-12 regulates bronchial epithelial cell proliferation and apoptosis. Cell Prolif 2008;41:988-1001.

-48 Mori S, Tanaka M, Nanba D, Nishiwaki E, Ishiguro $\mathrm{H}$, Higashiyama $\mathrm{S}$, Matsuura $\mathrm{N}$ : PACSIN3 binds ADAM12/meltrin alpha and up-regulates ectodomain shedding of heparin-binding epidermal growth factor-like growth factor. J Biol Chem 2003;278:46029_ 46034.

49 Yasui A, Matsuura K, Shimizu E, Hijiya N, Higuchi Y, Yamamoto S: Expression of splice variants of the human ADAM15 gene and strong interaction between the cytoplasmic domain of one variant and Src family proteins Lck and Hck. Pathobiology 2004;71: 185-192.
50 Edwards DR, Handsley MM, Pennington CJ: The ADAM metalloproteinases. Mol Aspects Med 2008;29:258-289.

51 Kveiborg M, Jacobsen J, Lee MH, Nagase H, Wewer UM, Murphy G: Selective inhibition of ADAM12 catalytic activity through engineering of tissue inhibitor of metalloproteinase 2 (TIMP-2). Biochem J 2010;430:79-86.

52 Fedak PW, Moravec CS, McCarthy PM, Altamentova SM, Wong AP, Skrtic M, Verma S, Weisel RD, Li RK: Altered expression of disintegrin metalloproteinases and their inhibitor in human dilated cardiomyopathy. Circulation 2006;113:238-245. 